\title{
Repellent Action of Carapa guianensis and Caesalpinia ferrea for flies species of Calliphoridae family
}

\author{
Ação repelente de Carapa guianensis e Caesalpinia ferrea \\ para espécies de moscas da família Calliphoridae
} Ciciane Pereira Marten Fernandes ${ }^{I^{*}}$ Camila Machado $^{I}$ Thiago Vaz Lopes ${ }^{I}$ Nilton Cunha Filho
Paulo Ribeiro Bretanha ${ }^{I}$ Sandro Schons ${ }^{I I}$ Samuel Rodrigues Félix ${ }^{I}$ Márcia de Oliveira Nobre

\section{ABSTRACT}

Myiases occur by the infestation of fly larvae in tissues of live vertebrate animals, resulting in economic loss. Phytotherapy is considered an important alternative in the control of insects, which may reduce the economic impacts. Carapa guianensis is a plant that has been studied as a repellent against mosquitoes and Caesalpinia ferrea is reported in tropical climates, and there are few studies about its repellent action. The present study was designed to evaluate the repellent action of $\boldsymbol{S} \boldsymbol{C}$. guianensis and $\boldsymbol{C}$. ferrea plants on flies species of the Calliphoridae family. W.O.T. traps containing deteriorated bovine liver and herbs cream of at concentrations of 20 and $50 \%$ were used to catch the flies. It was reported that the creams containing $\boldsymbol{C}$. ferrea at concentrations of 20 and $50 \%$ and $\boldsymbol{C}$. guianensis at the concentration of 50\% have repellent effect against species of Calliphoridae family.

Key words: repellency, Calliphoridae, myasis, ectoparasites.

\section{RESUMO}

Miíases ocorrem pela infestação de larvas de moscas em tecidos de animais vertebrados vivos, resultando em perdas econômicas Fitoterapia é considerada uma alternativa importante no controle de insetos, o que pode reduzir os impactos econômicos. Carapa guianensis é uma planta que tem sido estudada como um repelente contra mosquitos e Caesalpinia ferrea Mart. é encontrada em climas tropicais, e há poucos estudos sobre sua ação repelente. O presente estudo foi desenhado para avaliar a ação repelente das plantas $\boldsymbol{C}$. guianensis e C. ferrea Mart. em espécies de moscas da família Calliphoridae. Armadilhas WOT contendo figado bovino deteriorado e creme de ervas em concentrações de 20 e 50\% foram usadas para capturar as moscas. Verificou-se que os cremes contendo $\boldsymbol{C}$. ferrea Mart. em concentrações de 20 e 50\%, e $\boldsymbol{C}$. guianensis, na concentração de 50\%, têm efeito repelente contra as espécies da família Calliphoridae.

Palavras-chave: repelência, Calliphoridae, miíases, ectoparasitas.

\section{INTRODUCTION}

The repellency activity exerted by drugs such as ivermectin, pyrethrin or pyrethroid sprays are used to control insects, but it is observed that the use of such products leads to the development of resistance to chemical molecules thus bringing harmful effects to the infested bodies (CHAGAS et al., 2003).

The development of myiases occur by the infestation of larvae of flies in tissues of live vertebrate animals (ORFANOU et al., 2011), causing great losses in farm animals (CRAMER-RIBEIRO et al., 2002) and is a common problem in small animal veterinary practice (CRAMER-RIBEIRO et al., 2002; CARDOZO \& RAMADINHA, 2007). Several factors may predispose larval infestation, such as injuries caused by trauma and/or dermatological diseases (CARDOZO \& RAMADINHA, 2007). In this context, phytotherapy is considered an important alternative in the control of insects, which can reduce the economic impact (OLIVO et al., 2008). Repellent activity of herbal medicines such as citronella against mosquitoes, flies and ticks has been observed (OLIVO et al., 2008; LACHANGE \& GRANGE, 2014).

Carapa guianensis is a tree of the Meliaceae family, popularly known as "andiroba" or "kinky", cultivated in tropical climates and has been used as a repellent against mosquitoes (RIBAS\& CARREÑO, 2010). Caesalpinia ferrea is a tree of the Leguminosae-Caesalpinoidae family, known

\footnotetext{
'Faculdade de Veterinária, Universidade Federal de Pelotas (UFPel), 96010-900, Pelotas, RS, Brasil. E-mail: cici.marten@gmail.com. ${ }^{*}$ Corresponding author.

IIDepartamento de Medicina Veterinária, Fundação Universidade Federal de Rondônia (UNIR), Rolim de Moura, RO, Brasil. Received 05.20.15 Approved 09.23.15 Returned by the author 12.19.15 CR-2015-0727.R1
} 
as "jucá" or "ironwood", mainly found in tropical climates (LORENZI, 2002), and there are few studies on its repellent action.

Studies with herbal medicine aim to provide a variety of products with similar effectiveness of allopathic medicines, but at a low cost (MACIEL et al., 2002). Considering the biodiversity of the Brazilian plants and the medicinal potential that they have, it was aimed to evaluate the repellent action of andiroba and jucá plants on species of flies of the Calliphoridae family.

\section{MATERIALS AND METHODS}

Carapa guianensis oil and the hide of Caesalpinea ferrea fruit were obtained from the Universidade Federal de Rondônia (UFR). Both were collected from the city of Ji-Paraná (RO- Brazil) in January 2011. C. guanensis was identified in the herbarium at the Faculdade São Lucas/Porto Velho (RO) and a specimen is registered under the accession number 3672. $C$. ferrea was identified at the herbarium at the Centro Universitário Luterano de Ji-Paraná (CEULJI/ ULBRA) under the accession number 244.

To assess the repellent effect, pure $\boldsymbol{C}$. guanensis oil, and the powdered hide of $\boldsymbol{C}$. ferrea fruit were mixed and homogenized with petrol jelly (CAS n ${ }^{\circ}$ 8009-03-8), containing fatty acids and glycerol (GEBARA et al., 2005). These mixtures were made at a concentration of $20 \%$ and $50 \%$. Treatment groups were then divided as: Andiroba 20\% (A20 $80 \%$ petrol jelly and $20 \%$ oil), and $50 \%$ (A50- $50 \%$ petrol jelly and 50\% oil); and Jucá 20\% (J20 - 80\% petrol jelly and $20 \%$ powdered fruit hide) and $50 \%$ (J50 - 50\% petrol jelly and 20\% powdered fruit hide).

WOT (Wind Oriented Trap) traps were constructed according to the model of VIANNA et al. (2004), using deteriorated bovine liver as an attractive. Five hundred grams of deteriorated beef liver were placed inside each trap as bait. The bait was placed in a plastic pot with water in order to keep it moist. In each trap $5 \mathrm{ml}$ of the cream treatments A20, A50, J20, J50 were added, and one trap containing only deteriorated beef liver was used as a positive control (PC) (PC $100 \%$ petrol jelly in deteriorated bovine liver).

The experiment was conducted in January, in the town of Capão do Leão $\left(31^{\circ} 45^{\prime} 00^{\prime \prime} \mathrm{S}, 52^{\circ}\right.$ 30 '00" W, altitude $21.00 \mathrm{~m}$ ), state of Rio Grande do Sul, Brazil. The region has a subtropical climate, and six repetitions of the assay were conducted. During the experiment, temperatures ranged from $15^{\circ} \mathrm{C}$ to $34^{\circ} \mathrm{C}$ and humidity from $20 \%$ to $80 \%$
(CLIMATEMPO, 2012). WOT Traps were placed in an area equivalent to two acres in open fields with native pasture. Five traps were used and installed ten meters equidistant from each other, suspended at 1.20 meters above the ground. The traps stayed in place for 24 hours, after which the flies were collected, the liver and herbal medicine changed, and a new repetition started. After the capture period, the amount and species of the flies within each trap were identified. These were placed in glass vials, frozen at $-20^{\circ} \mathrm{C}$ and compared to the identification key proposed by CARVALHO \& RIBEIRO (2000).

For data analysis, the protection index $(\%)$ was used based on the formula of ABBOTT (1925), in which it is determined the number of flies present in the control group (C) and number of flies in the present treatments $(\mathrm{T})[(\mathrm{C}-\mathrm{T}) / \mathrm{C}] \mathrm{x} 100$. The KruskalWallis test was used at a significance level of 5\% for statistical analysis using Statistics 9.0 software.

\section{RESULTS}

Flies of the Calliphoridae family, captured in WOT traps during the experiment were: Lucilia eximia (32.81\%); Chrysomya albiceps (25\%); Chrysomya megacephala (21.31\%), Lucilia sericata (7.40\%), Lucilia cuprina (1.5\%) and Sarconesia chlorogaster $(1.5 \%)$ (Table 1). The largest number of flies caught occurred in the collection days with the highest temperature and humidity, respectively days 2 and 5 with temperatures of $29^{\circ} \mathrm{C}$ and $25^{\circ} \mathrm{C}$, and humidity $80 \%$ and $77 \%$, respectively (Table 1 ). Flies were found in every repetition in the traps treated with the positive control (PC), while the best repellency activity was observed in the traps with $\boldsymbol{C}$. ferrea at concentrations of $20 \%$ (J20) and 50\% (J50). No flies were captured in traps with $\boldsymbol{C}$. ferrea of $50 \%$, while only one fly (genus Lucilia eximia) was found in those treated with $\boldsymbol{C}$. ferrea of $20 \%$. In the $\boldsymbol{C}$. guianensis trap with $50 \%$ (A50) three flies were captured in the six days of collection, and in the treatment with $\boldsymbol{C}$. guianensis of $20 \%$ (A20) several species of flies were collected, demonstrating less repellent action of the herbal medicine at this concentration.

In the repellency evaluation of plants by the use of the ABBOTT (1925) formula, it is possible to observe that traps containing $\boldsymbol{C}$. ferrea at $20 \%(\mathrm{~J} 20)$ and $50 \%$ (J50) presented a higher repellency, with $97.5 \%$ and $100 \%$, respectively, than those containing C. guianensis at 50\% (A50) and 20\% (A20) with $92.5 \%$ and $60 \%$ repellency, respectively. As for the repellency of herbal medicines compared with the positive control group, significant differences were 
Table 1 - Demonstration of the repellency activity of Caesalpinia ferrea and Carapa guianensis against flies caught in WOT traps.

\begin{tabular}{|c|c|c|c|c|c|c|c|c|}
\hline & \multicolumn{2}{|c|}{ 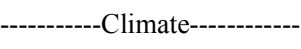 } & \multirow{2}{*}{ Calliphoridae flies } & \multicolumn{5}{|c|}{ 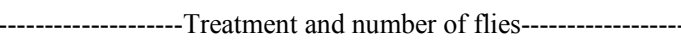 } \\
\hline & $\mathrm{TempC}^{\circ}$ & Humid \% & & $\mathrm{CP}$ & A 20 & $\mathrm{~A} 50$ & $\mathrm{~J} 20$ & $\mathrm{~J} 50$ \\
\hline 1 & 27 & 55 & Lucilia eximia & 1 & 0 & 0 & 0 & 0 \\
\hline 2 & 25 & 77 & Lucilia eximia & 9 & 1 & 0 & 0 & 0 \\
\hline 3 & 35 & 40 & Sarconesia chlorogaster & 1 & 0 & 0 & 0 & 0 \\
\hline 4 & 33 & 45 & Lucilia eximia & 3 & 0 & 0 & 0 & 0 \\
\hline \multirow[t]{5}{*}{5} & 29 & 80 & Chrysomya albiceps & 6 & 8 & 0 & 0 & 0 \\
\hline & & & Chrysomya megacephala & 8 & 3 & 1 & 0 & 0 \\
\hline & & & Lucilia cuprina & 1 & 0 & 0 & 0 & 0 \\
\hline & & & Lucilia eximia & 7 & 0 & 2 & 1 & 0 \\
\hline & & & Lucilia sericata & 2 & 2 & 0 & 0 & 0 \\
\hline \multirow[t]{2}{*}{6} & 25 & 67 & Chrysomya albiceps & 1 & 2 & 0 & 0 & 0 \\
\hline & & & Chrysomya megacephala & 1 & 0 & 0 & 0 & 0 \\
\hline
\end{tabular}

observed: J50 $(\mathrm{P}<0.01), \mathrm{J} 20(\mathrm{P}<0.01044)$ and A50 $(\mathrm{P}<0.01077)$. The efficacy assessment among the different plant extracts showed that, treatment with A20 was significantly more effective $(\mathrm{P}<0.0026)$ when compared to the other groups (A50, J20, and J50) (Table 2).

\section{DISCUSSION}

The assessment of $\boldsymbol{C}$. ferrea and C. guianensis's repellent action on flies of the Calliphoridae family yielded promising results, especially for the jucá (C. ferrea) compound. The flies of the Calliphoridae family captured during this study are common agents causing larval infestations in veterinary medicine. Furthermore, these species have a particular importance in public health, acting as vectors to other pathogens, aggravated by their synantropic nature (CARVALHO \& RIBEIRO, 2000).

The largest amount of captured flies was on days with higher temperatures and relative humidity. This was expected, and has been repeatedly

Table 2 - Average number of flies present in traps, standard deviation and Protection Index calculated.

\begin{tabular}{lcc}
\hline Preparation & Mean (S.D.) & Protection Index calculated (\%) \\
\hline A20 & $3.3(6.3) \mathrm{a}$ & 60 \\
A50 & $0.5(1.2) \mathrm{b}$ & 92.5 \\
J20 & $0.5(1.2) \mathrm{b}$ & 97.5 \\
$\mathrm{~J} 50$ & $0.0(0.0) \mathrm{b}$ & 100 \\
CP & $7.5(9.9) \mathrm{a}$ & 0 \\
\hline
\end{tabular}

Different letters represent statistically different results in the column (Kruskal Wallis $\mathrm{P}<0.05$ ). demonstrated by other authors (GOMES et al., 2000; CORRÊA et al., 2010). These species of flies are seasonal, occurring in greater numbers in months and regions with high temperatures and rainfall.

According to NERIO et al. (2010), the repellent capacity of a given plat extract will depend on the specific compounds, and their concentration, present in the extract. To produce the creams used in this study, petroleum jelly (Vaseline) was used. As an oily with inodorous substance, this vehicle has no effect on its own, but probably allowed the aggregation of the active substances in the plant extracts. Furthermore, petroleum jelly has been shown to allow a controlled and moderate release of volatile compounds in these extracts, enhancing the period of effect.

The treatment of larval infestations in veterinary practice is usually done through topic or systemic application of chemicals to kill the larvae, with the mechanical removal of accessible instars, often requiring anesthesia and anti-inflammatory/ antibiotic support (MORETTI \& THYSSEN, 2006; CARDOZO \& RAMADINHA, 2007). Using natural products to avoid infestations is a safe way to improve pet's quality of life, avoiding unnecessary discomfort, and appealing to consumer demands. Likewise, the low cost of such products make them particularly for preparations aimed at livestock protection, associated with environmental modifications which have been shown to reduce the number of infestations in these species. (MORETTI \& THYSSEN, 2006; CARDOZO \& RAMADINHA, 2007). Plant based products can be produced at reasonable costs with satisfactory results, as shown in this study. Although further research should be carried out on the effects of these plants on other arthropods, such as ticks and mites, and in combination with other dematological 
products, there is no doubt that they efficiently repeal flies of the Calliphoridae family.

\section{CONCLUSION}

In the conditions considered here, preparations containing Andiroba at 50\%, and Jucá, both at 20 and 50\%, have repellant effect against Chrysomya albiceps; Chrysomya megacephala, Lucilia cuprina, Lucilia eximia, Lucilia sericata and Sarconesia chlorogaster, all flies of the Calliphoridae family.

\section{ACKNOWLEDGEMENTS}

Coordenação de Aperfeiçoamento de Pessoal de Nível Superior (CAPES) and Conselho Nacional de Desenvolvimento Científico e Tecnológico (CNPq) for scholarships and financial aid.

\section{REFERENCES}

ABBOTT, W.S.A. Method of computing the effectiveness of an insecticide. Journal of Economic Entomology, v.18, p.265-266, 1925. Available from: <http://www.sciencedirect.com/science/ article/pii/S0304401704003486>. Accessed: Nov. 12, 2008. doi: 10.1016/j.vetpar.2004.08.001

CARDOZO, S.V.; RAMADINHA, R.R. Evaluation of myiasis treatment in dogs using nitenpyram. Revista Brasileira de Ciência Veterinária, v.14, p.139-142, 2007. Available from: <http://www. uff.br/rbcv/ojs/index.php/rbcv/article/view/433>. Accessed: Dec. 21, 2014. doi: 10.4322/rbcv.2014.250.

CARVALHO, C.J.B.; RIBEIRO, P.B. Rate of development of forensically-important Dipterain southern Brazil. Revista Brasileira de Parasitologia Veterinária, v.9, p,169-173, 2000. Available from: <http://www.scielo.br/scielo.php?script=sci_artte xt\&pid=S0085-56262010000400014>. Accessed: Oct. 12, 2012. doi: $10.1590 / \mathrm{S} 0085-56262010000400014$

CHAGAS, A.C.S. et al. Sensibility of Boophilus microplus tick to solvents. Ciência Rural, v.33, p.109-114, 2003. Available from: $<$ http:// www.scielo.br/pdf/cr/v33n1/14151.pdf>. Accessed: Oct. 12, 2012.

CLIMATEMPO, 2012. Available from: <http://www.climatempo. com.br>. Accessed: Feb. 2012.

CORRÊA, E.C. et al. Chrysomya (Diptera: Calliphoridae) relative abundance and species seasonality in the Pantanal, State of Mato Grosso do Sul, Brazil. Revista Brasileira de Parasitologia Veterinária, v.19, n.2, p.85-88, 2010. Available from: <http:// www.scielo.br/pdf/rbpv/v19n2/03.pdf>. Accessed: Oct. 12, 2012.

CRAMER-RIBEIRO, B.C. et al. Inquiry of cases of myiasis by Cochliomyia hominivorax in dogs of the southern zone of Rio de Janeiro city in 2000. Brasilian Journal of Veterinary Research and Animal Science, v.39, n.4, p.171-175, 2002 Available from: $\quad<$ http://www.scielo.br/scielo.php?pid=S1413$95962002000400002 \&$ script $=$ sci abstract\&tlng=pt $>$. Accessed: Jan 02, 2015. doi: 10.1590/S1413-95962002000400002.

GEBARA, K.S. et al. Estudo da viabilidade de utilização do óleo de canola em formas farmacêuticas de aplicação tópica.
In: REUNIÃO ANUAL DA SBPC, 57., 2005, Fortaleza, CE. 2005. Anais... Fortaleza: SBPC, 2005. Available from: $<$ http:// www.sbpcnet.org.br/livro/57ra/programas/senior/RESUMOS/ resumo 3177.html>. Accessed: Nov. 18, 2012.

GOMES, A. et al. Sazonalidade da mosca-varejeira, Cochliomyia macellaria (Diptera: Calliphoridae), na região dos cerrados, Campo Grande, MS. Revista Brasileira de Parasitologia Veterinária, v.9, p.125-128, 2000. Available from: <http:// www.cbpv.org.br/rbpv/documentos/922000/c92125_128.pdf $>$. Accessed: Nov. 20, 2012.

LACHANGE, S.;GRANGE, G. Repellent effectiveness of seven plant essential oils, sunflower oil and natural insecticides against horn flies on pastured dairy cows and heifers. Medical and Veterinary Entomology, v.28, p.193-200, 2014. Available from: $<$ http://onlinelibrary.wiley.com/doi/10.1111/mve.12044/epdf $>$. Accessed: Feb. 04, 2015. doi: 10.1111/mve.12044.

LORENZI, H. Árvores brasileiras: manual de identificação e cultivo de plantas arbóreas do Brasil. Nova Odessa: Instituto Plantarum, 2002. 162p.

MACIEL, M.A. et al. Plantas medicinais: a necessidade de estudos multidisciplinares. Quimica Nova, v.25, n.3, p.429-438, 2002. Available from: <http://www.scielo.br/scielo.php?pid=S0100404 22002000300016\&script $=$ sci_abstract\&tlng=pt $>$. Accessed: Feb. 04, 2015. doi: 10.1590/S0100-40422002000300016.

MORETTI, T.C.; THYSSEN, P.J. Primary myiasis in a domestic rabbit caused by Lucilia eximia (Diptera: Calliphoridae) in Brazil: case report. Arquivo Brasileiro de Medicina Veterinária e Zootecnia, v.58, n.1, p.28-30, 2006. Available from: <http:// www.scielo.br/scielo.php?pid=S010209352006000100005\&scrip $\mathrm{t}=$ sci_abstract\&tlng=pt $>$. Accessed: Dec. 30, 2012. doi: 10.1590/ S0102-09352006000100005.

NERIO, L.S. et al. Repellent activity of essential oils: areview. Bioresourse Technology, v.101, p.372-378, 2010. Available from: $<$ http://www.researchgate.net/profile/Luz_Stella_Nerio_Quintana/ publication/26788511_Repellent_activity_of_essential_oils_a review/links/09e4150ea018289db6000000.pdf $>$. Accessed: Feb. 04, 2015. doi: 10.1016/j.biortech.2009.07.048.

OLIVO, C.J. et al. Citronella oil on the control of catle ticks. Ciência Rural, v.38, n.2, p.406-410, 2008. Available from: $<$ http://www. scielo.br/pdf/cr/v38n2/a18v38n2.pdf>. Accessed: Dec. 30, 2012.

ORFANOU, D.C. et al. Myiasis in a dog shelter in Greece: Epidemiological and clinical features and therapeutic considerations. Veterinary Parasitology, v.181, p.374-378, 2011. Available from: <http://europepmc.org/abstract/MED/21536388>. Accessed: Dec. 30, 2012. doi: 10.1016/j.vetpar.2011.04.006.

RIBAS, J.; CARREÑO, A.M. Avaliação do uso de repelentes contra picada de mosquitos em militares na Bacia Amazônica. Anais Brasileiros de Dermatologia, 85, n.1, p.33-38, 2010. Available from: <http://www.scielo.br/scielo.php?pid=S0365059 $62010000100004 \&$ script $=$ sci abstract $\&$ tlng $=\mathrm{pt}>$. Accessed: Nov. 20, 2012. doi: 10.1590/S0365-05962010000100004.

VIANNA, E.E.S. et al. Abundância e flutuação populacional das espécies de Chrysomya (Diptera: Calliphoridae) em Pelotas, Rio Grande do Sul, Brasil. Iheringia, Série Zoologia, v.94, n.3, p.231-234, 2004. Available from: <http://www.scielo.br/pdf/isz/ v94n3/22872.pdf $>$. Accessed: Mar. 04, 2015. 